TITLE:

\title{
A Rat Model of Dilated Cardiomyopathy to Investigate Partial Left Ventriculectomy( Abstract_要旨 )
}

$\operatorname{AUTHOR}(\mathrm{S}):$

Yuasa, Sadatoshi

CITATION:

Yuasa, Sadatoshi. A Rat Model of Dilated Cardiomyopathy to Investigate Partial Left Ventriculectomy. 京都大学, 2002, 博士(医学)

ISSUE DATE:

2002-11-25

URL:

http://hdl.handle.net/2433/149363

RIGHT: 


\begin{tabular}{|c|c|}
\hline 氏 & 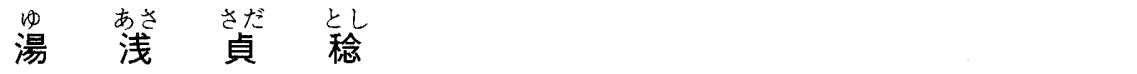 \\
\hline 学位(専攻分野) & 博 士 (医 学) \\
\hline 学位 記 番 号 & 論 医 博 第 1794 号 \\
\hline 学位授与の日付 & 平成 14 年 11 月 25 日 \\
\hline 学位授与の要件 & 学 位 規則 第 4 条第 2 項該当 \\
\hline 学位論文題目 & $\begin{array}{l}\text { A Rat Model of Dilated Cardiomyopathy to Investigate Partial Left } \\
\text { Ventriculectomy } \\
\text { (ラット拡張型心筋症 (DCM) モデルを用いた左室縮小形成術（バチスタ手 } \\
\text { 術)) } \\
\text { (主 查) }\end{array}$ \\
\hline
\end{tabular}

論文内容 の 要旨

数年前に心不全に対する外科的治療の新しい概念が提案された。左室縮小形成術（バチス夕手術）と言われるもので, 特 発性拡張型心筋症（DCM）またはうっ血性心不全患者の左室側壁を切除することにより, 左心機能の改善を計る手術であ った。結果については必ずしも同一の効果ではなく，また血流動態的効果についても詳細な検討がなされていなかった。そ の一つの問題点として適当な動物モデルの不在が挙げられる。

本研究では特発性拡張型心筋症（DCM）に対する, 左室縮小形成術（バチス夕手術）の効果を調べるため, ラット拡張 型心筋症（DCM）モデルを開発し術前後の心機能を評価することを目的とした。

ダール食塩感受性ラット $(\mathrm{n}=18)$ を 3 群に分け， 1 群（n=6）は生後 7 週目より 8 \%高食塩食を開始した。 2 群 $(\mathrm{n}=$ 6）は 8 週目より開始， 3 群は 9 週目より開始した。血圧は tail-cuff 法にて計測，心内腔計測は心エコーにて計測した。

1 群および 2 群の収縮期血圧は徐々に上昇し10週目から11週目には $200 \mathrm{mmHg}$ まで上昇し, 明らかな心不全症状を呈す ることなく20週目前後までにすべてが死亡した。しかし 3 群は14週目まで徐々に $196 \pm 15$ (平均士標準偏差) $\mathrm{mmHg}$ まで 上昇し, 拡張末期左室短径 (EDD) は $6.2 \pm 0.4 \mathrm{~mm}(5.1 \pm 0.7 \mathrm{~mm}$ : コントロール), 短縮率 (FS) は $77 \pm 3 \%(68 \pm$ $3 \%$ : コントロール）となった。24週目から 25 週目にかけて，すべてが心不全症状を示すようになり，収縮期血圧は高値を

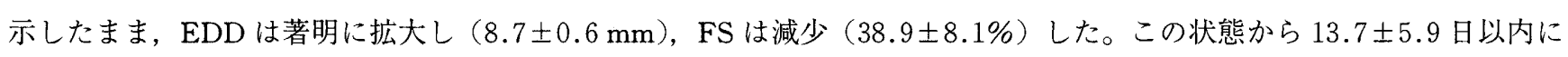
すべてが死亡した。病理組織では主に前後乳頭筋間の心内膜下側血管周囲に繊維化が認められた。肺野では肺胞内に多量の 漏出液の貯留㧍よび毛細血管の出血を認めた。この 3 群を左室縮小形成術モデルに用いることにした。

DCM モデルラット（n=8）を経口気管挿管，イソフルレン麻酔下で左第 5 肋間開胸にて心臓に到達した。術前に心エコ 一にて前後乳頭筋を確認しておき，心拍動下に両乳頭筋問および心尖部をフェルト付きモノフィラメント糸で左室縮小した。 血行動態の安定を確認した後閉胸した。麻酔からの覚醒を確認後に抜管してからケージに戻し，以後も高食塩食を継続した。 結果は, EDD は術前 $8.6 \pm 0.5 \mathrm{~mm}$ から術後 $7.0 \pm 0.5 \mathrm{~mm} （ \mathrm{P}<0.001 ）$ と減少した。FSは $36 \pm 1 \%$ から $52 \pm 6 \%(\mathrm{P}<$ 0.05）と改善傾向を示した。血圧は $224 \pm 14 \mathrm{mmHg}$ から $139 \pm 30 \mathrm{mmHg} （ \mathrm{P}<0.05 ）$ と低下傾向を示した。壁張力は $270 \pm$ 70dyne $/ \mathrm{cm}^{2}$ から $98 \pm 35 \mathrm{dyne} / \mathrm{cm}^{2} （ \mathrm{P}<0.05 ）$ と低下傾向を示した。2 匹は不整脈または高血圧に関与した出血により周術 期に死亡した。しかし他の 6 匹の術後 3 週間の生存率は60\%であった。これらの結果より拡張末期左室短径を減少させたこ とは収縮能の改善をもたらしたと言える。

ダール食盐感受性ラットを用いることにより，左室縮小形成術の効果を調べるためのラット拡張型心筋症（DCM）モデ ルを開発することが出来た。このモデルを用いることにより, より有効な左室縮小形成術の方法, 適応および効果について の科学的調查が可能になるものと思われる。

\section{論 文 審 査の結 果 の 要 旨}

左室縮小形成術 (バチス夕手術) は特発性据張型心筋症（DCM）の左室側壁を切除することにより左心機能の改善を計 
る手術であるが，結果は必ずしも均一ではない。その一つの問題点として科学的データの不足が挙げられる。それには心不 全で左室が十分に搪張し，それでいて左室形成に耐えられるだけの余力を残した適当な動物モデルが必要である。本研究で は上記の条件をみたすラット拡張型心筋症モデルを開発し術前後の心機能を評価することを目的としている。ダール食塩感 受性ラットを 3 群に分け，1群（n=6）は生後 7 週目より高塩食を開始し， 2 群（n=6）は8 週目， 3 群（n=6）は 9 週 目より開始した。 1 群および2 群は，明らかな心不全症状を呈することなく死亡した。しかし，3群はすべてが心不全症状 を示すようになり，拡張末期左室短径（EDD）は著明に拡大し，短縮率（FS）は減少した。この 3 群をモデルに用いるこ

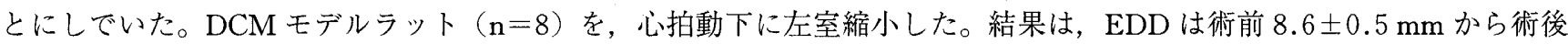
$7.0 \pm 0.5 \mathrm{~mm}(\mathrm{P}<0.001)$ と減少し，FS は $36 \pm 1 \%$ から $52 \pm 6 \%(\mathrm{p}<0.05 ）$ と改善傾向を示した。これより拡張末期左室 短径を減少させたことが収縮能の改善をもたらしたと言える。左室縮小形成術の効果を調べるためのラット DCM モデルを 開発することが出来たと考えられる。このモデルを用いることにより，より有効な左室縮小形成術の方法，効果について科 学的調查が可能になるものと思われる。

したがって，本論文は博士（医学）の学位論文として価値あるものと認める。なお，本学位授与申請者は，平成14年10月 23日実施の論文内容とそれに関連した試問を受け，合格と認められたものである。 